\title{
The suppressor of cytokine signalling 2 (SOCS2) is a key repressor of insulin secretion
}

\author{
P. Lebrun • E. Cognard • P. Gontard • R. Bellon-Paul • C. Filloux • M. F. Berthault \\ C. Magnan • J. Ruberte • M. Luppo • A. Pujol • N. Pachera • A. Herchuelz • F. Bosch • \\ E. Van Obberghen
}

Received: 17 January 2010 / Accepted: 1 April 2010 / Published online: 25 May 2010

(C) Springer-Verlag 2010

\begin{abstract}
Aims/hypothesis Suppressor of cytokine signalling (SOCS) proteins are powerful inhibitors of pathways involved in survival and function of pancreatic beta cells. Whereas SOCS1 and SOCS3 have been involved in immune and inflammatory processes, respectively, in beta cells, nothing is known about SOCS2 implication in the pancreas.

Methods Transgenic ( $\operatorname{tg})$ mice were generated that constitutively produced SOCS2 in beta cells ( $\beta$ SOCS2) to define whether this protein is implicated in beta cell functioning and/or survival.
\end{abstract}

Electronic supplementary material The online version of this article (doi:10.1007/s00125-010-1786-9) contains supplementary material, which is available to authorised users.

P. Lebrun $(\bowtie) \cdot$ E. Cognard $\cdot$ P. Gontard $\cdot$ R. Bellon-Paul $\cdot$

C. Filloux $\cdot$ E. Van Obberghen $(\bowtie)$

INSERM U907,

Avenue de Valombrose,

06107 Nice, France

e-mail: plebrun@unice.fr

e-mail: vanobbeg@unice.fr

P. Lebrun • E. Cognard · P. Gontard · R. Bellon-Paul • C. Filloux

E. Van Obberghen

Faculté de Médecine, Institut de Génétique et Signalisation

Moléculaire (IFR50), Université de Nice-Sophia Antipolis,

Nice, France

M. F. Berthault $\cdot$ C. Magnan

CNRS EAC 4413, University Paris Diderot,

Paris, France

J. Ruberte $\cdot$ M. Luppo $\cdot$ A. Pujol $\cdot$ F. Bosch

Center of Animal Biotechnology and Gene Therapy and

Department of Animal Health and Anatomy,

School of Veterinary Medicine,

Universitat Autonoma de Barcelona,

Barcelona, Spain
Results Constitutive production of SOCS2 in beta cells leads to hyperglycaemia and glucose intolerance. This phenotype is not a consequence of decreased beta cell mass or inhibition of insulin synthesis. However, insulin secretion to various secretagogues is profoundly altered in intact animals and isolated islets. Interestingly, constitutive SOCS2 production dampens the rise in cytosolic free calcium concentration induced by glucose, while glucose metabolism is unchanged. Moreover, tg islets have a depletion in endoplasmic reticulum $\mathrm{Ca}^{2+}$ stores, suggesting that SOCS2 interferes with calcium fluxes. Finally, in

J. Ruberte $\cdot$ M. Luppo $\cdot$ A. Pujol $\cdot$ F. Bosch Center of Animal Biotechnology and Gene Therapy and Department of Biochemistry and Molecular Biology, School of Veterinary Medicine,

Universitat Autonoma de Barcelona,

Barcelona, Spain

J. Ruberte $\cdot$ M. Luppo $\cdot$ A. Pujol $\cdot$ F. Bosch

CIBER of Diabetes and Associated Metabolic

Diseases (CIBERDEM), Spain

URL: http://www.ciberesp.es

N. Pachera $\cdot$ A. Herchuelz

Laboratoire de Pharmacodynamie et de Thérapeutique,

Université Libre de Bruxelles (ULB),

Brussels, Belgium

E. Van Obberghen

Laboratoire de Biochimie, Hôpital Pasteur, CHU de Nice,

Nice, France 
BSOCS2 mice proinsulin maturation is impaired, leading to an altered structure of insulin secretory granules and augmented levels of proinsulin. The latter is likely to be due to decreased production of prohormone convertase 1 (PC1/3), which plays a key role in proinsulin cleavage.

Conclusions/Interpretations SOCS2 was shown to be a potent regulator of proinsulin processing and insulin secretion in beta cells. While its constitutive production is insufficient to induce overt diabetes in this mouse model, it causes glucose intolerance. Thus, increased SOCS2 production could be an important event predisposing to beta cell failure.

Keywords Glucose intolerance - Insulin secretion . Pancreatic beta cell $\cdot$ Proinsulin maturation $\cdot$ SOCS .

Transgenic mice

$\begin{array}{ll}\text { Abbreviations } & \\ \text { CICR } & \text { Calcium-induced calcium release } \\ \text { CPE } & \text { Carboxypeptidase E/H } \\ \text { ER } & \text { Endoplasmic reticulum } \\ \text { GH } & \text { Growth hormone } \\ \text { HFD } & \text { High-fat diet } \\ \text { IPGTT/OGTT } & \begin{array}{l}\text { Intraperitoneal glucose tolerance test/oral } \\ \text { glucose tolerance test }\end{array} \\ \text { JAK } & \text { Janus kinase } \\ \text { PC } & \text { Prohormone convertase } \\ \text { r-t PCR } & \text { Real-time PCR } \\ \text { RIP } & \text { rat insulin promoter } \\ \text { SERCA } & \text { Sarcoendoplasmic reticulum } \mathrm{Ca}^{2+} \\ \text { SOCS } & \text { ATPase } \\ \text { STAT } & \text { Suppressor of cytokine signalling } \\ \text { tg } & \text { Signal transducer and activator of } \\ \text { WT } & \text { transcription } \\ & \text { Transgenic } \\ & \text { Wild-type }\end{array}$

\section{Introduction}

Beta cell dysfunction is fundamental in the development of both type 1 and type 2 diabetes. While it is accepted that autoimmune destruction of islets is responsible for type 1 diabetes, the mechanisms of pancreatic failure involved in deterioration of insulin resistance to type 2 diabetes remain to be clarified. Generally speaking, in the prediabetic obese state insulin resistance is coupled to compensatory hyperinsulinaemia, followed by beta cell failure and ensuing chronic hyperglycaemia characteristic of diabetes. As a consequence of insulin resistance several perturbations occur, such as increased circulating levels of cytokines and metabolites, and they together participate in beta cell dysfunction [1-4].

The suppressor of cytokine signalling (SOCS) proteins have received much attention for their inhibitory role in signalling by cytokines [5]. During recent years, SOCS have emerged as potent modulators of additional pathways, such as those induced by insulin and growth hormone $(\mathrm{GH})$ [6-10]. Concerning the pancreas, the role of SOCS proteins has so far been mainly studied in relation to the action of cytokines [11-13]. Among the different SOCS, SOCS3 has been the most intensively studied in pancreatic islets. Recent data from our laboratory demonstrate that in pancreatic beta cells SOCS3, induced by cytokines, interacts with the insulin receptor, inhibiting the recruitment of IRS proteins and hence downstream signals [14]. Several studies from Billestrup et al. reported that SOCS3 constitutively produced in beta cells reduces cytokine $[15,16]$ and $\mathrm{GH}[9,17]$ signals in these cells. Indeed, the latter observations clearly demonstrate the important role of SOCS3 in inhibiting deleterious cytokine signalling in beta cells and hence favouring islet survival $[15,16]$. In addition, using a mouse model producing SOCS3 constitutively in beta cells, Billestrup et al. revealed the implication of SOCS3 in the regulation of GH signalling in the endocrine pancreas [9].

Several studies illustrate the impact of SOCS2 on somatic growth through regulation of GH/IGF1 pathways $[8,18,19]$. In addition, SOCS2 plays a role in the nervous system [20-22] and the immune response [23] and might participate in certain cancers [24-26]. To date, little is known about the impact of SOCS2 on pancreatic physiology. However, it has been recently shown that SOCS2 single nucleotide polymorphisms (SNPs) can be associated with type 2 diabetes [27]. Moreover, the authors found that constitutive production of SOCS2 in MIN6 beta cells reduces glucose-stimulated insulin secretion. Several genome-wide analyses have recently revealed multiple genetic loci specifically associated with diabetes [28, 29]. It is intriguing that the products of most of those genes are potentially involved in beta cell function, suggesting that beta cells are chief players in the pathogenesis of type 2 diabetes, and that predisposition to this disease is likely to be related to inappropriate expression of specific beta cell genes. Given the role of SOCS2 in the regulation of growth and cytokine signals, we put forward the idea that SOCS2 could play a key role in beta cell function. To test our view, we generated a mouse model producing SOCS2 constitutively in beta cells, and studied the ability of these mice to maintain glucose homeostasis. 


\section{Methods}

Generation of transgenic mice producing SOCS2 protein in beta cells

The vector containing the rat insulin promoter (RIP) 1 is a gift from B. Thorens (University of Lausanne, Lausanne, Switzerland), and has been previously described [30]. Briefly, a flag-tagged complete coding sequence of mouse Socs 2 cDNA (gift from D. Hilton, The Walter and Eliza Hall Institute of Medical Research, Parkville, VIC, Australia) [31] was introduced in pXf3-RIP1. Our mice had a C57BL/6 background (Elevage R. Janvier, Le Genest St Isle, France). Care and use of mice was in accordance with the Guidelines of the French National Institute of Health and Medical Research (INSERM, France).

Animal studies and metabolic analysis

Mice were housed on a $12 \mathrm{~h}$ light/dark cycle and put when 6 weeks old on a high-fat diet (HFD) (42\% fat, TD-88137; Harlan Teklab, Madison, WI, USA) or standard chow diet with free access to diet and water. Body weight was measured weekly. Blood glucose was measured using the One Touch glucometer system (Lifescan Inc., Milpitas, CA, USA), serum insulin using Ultra Sensitive Rat Insulin ELISA kit (Crystal Chem, Downers Grove, IL, USA), and proinsulin using Rat/ Mouse Proinsulin ELISA kit (Mercodia AB, Uppsala, Sweden). For intraperitoneal and oral glucose tolerance tests (IPGTT and OGTT, respectively) $2 \mathrm{mg} / \mathrm{g}$ body weight of glucose was given. For glucose- and arginine-stimulated insulin secretion, animals were starved overnight and injected intraperitoneally with glucose $(2 \mathrm{mg} / \mathrm{g})$ or arginine $(3 \mathrm{mg} / \mathrm{g})$.

Pancreatic extracts and insulin content

Insulin was extracted from whole pancreas with acid/ alcohol as previously described [32] and hormone content was measured using ELISA assay (Mercodia AB).

RNA extraction, reverse transcription and real-time PCR (r-t PCR)

Isolated islets were homogenised in Trizol (Invitrogen Life Technologies Inc., Gaithersburg, MD, USA), RNAs were extracted and reverse-transcribed (High capacity, Applied Biosystems Inc., Foster City, CA, USA). cDNAs were analysed using SYBR Green r-t PCR (ABI PRISM 7000 Sequence Detector System). The amount of cDNA used in each reaction was normalised to housekeeping $36 b 4$ (also known as $R p l p 0$ ) cDNA.
Protein extraction and western blotting

For protein extraction, isolated islets were lysed in RIPA buffer and proteins were quantified (BCA protein assay kit; Pierce, Thermo Fisher Scientific, Rochford, IL, USA), separated by SDS-PAGE, transferred to polyvinylidene fluoride (PVDF) membranes and blotted with antibodies. Immunoreactive proteins were revealed by enhanced chemiluminescence (Millipore, Billerica, MA, USA). Antibodies to SOCS2 were from Cell Signaling Technology, and to tubulin from Sigma.

Insulin secretion by isolated islets

Islets were isolated according to Kulkarni et al. [33]. Following isolation, islets were incubated overnight in RPMI medium (7 mmol/1 glucose; $0.2 \%$ [wt/vol.] BSA). Next, islets were deprived in $\mathrm{KRBH}$ medium $(1 \mathrm{mmol} / 1$ glucose for $45 \mathrm{~min}$ ) and stimulated with various secretagogues in the presence of $2.8 \mathrm{mmol} / 1$ glucose. Islet supernatant fraction was collected after $1 \mathrm{~h}$ of treatment and insulin was extracted from islets with acid/alcohol solution (1.5\%/75\%).

Intracellular $\mathrm{Ca}^{2+}$ concentration measurements

Islets were incubated with fura-2 acetoxymethyl ester (final concentration $2 \mu \mathrm{mol} / \mathrm{l}$ ) for $60 \mathrm{~min}$ at $37^{\circ} \mathrm{C}$ in a Krebs-Ringer bicarbonate-buffered solution containing $2.8 \mathrm{mmol} / 1$ glucose. The coverslips were then analysed by epifluorescence (Diaphot TDM, Nikon). Fura-2 fluorescence of single islets was measured by dual excitation fluorimetry using a camerabased image analysis system (Metafluor, Universal Imaging). Data are presented as the ratios of the 340 and $380 \mathrm{~nm}$ signals as described [34].

Measurement of glucose metabolism

The methods to measure $\mathrm{D}-\left[5-{ }^{3} \mathrm{H}\right]$ glucose metabolism and $\mathrm{D}-\left[\mathrm{U}-{ }^{14} \mathrm{C}\right]$ glucose oxidation in islets are described [35-37].

Histological analysis

For transmission electron microscopic analysis pancreases were fixed in $2.5 \%$ (vol./vol.) glutaraldehyde and $2 \%$ (vol./vol) paraformaldehyde, post-fixed in 1\% (vol./vol.) osmium tetroxide, stained in aqueous uranyl acetate, dehydrated and embedded in epoxy resin. Ultrathin sections $(70 \mathrm{~nm})$ were stained using lead citrate and examined by transmission electron microscopy (Jeol 1400; Hitachi).

For immunohistochemistry, the following antibodies were used: guinea pig anti-insulin antibody (1:100; Sigma, 
St Louis, MO, USA); rabbit anti-mouse SOCS-2 antibody (1:50; Santa Cruz Biotechnology, Santa Cruz, CA, USA); mouse anti-human PC1 antibody (1:50; Abd Serotec, Raleigh, NC, USA); anti-rabbit Alexa Fluor 488 (1:100; Invitrogen); anti-guinea pig Alexa Fluor 568 (1:100; Invitrogen); anti-mouse IgG biotinylated (1:250; Vector Laboratories, Ontario, LTN, Canada); and streptavidin Alexa Fluor 488 (1:100; Molecular Probes). To-Pro-3 iodide (Molecular Probes, Invitrogen) for nuclear counterstaining was used for laser-scanning confocal analysis (TCS SP2; Leica Microsystems).

\section{Morphometry}

Immunohistochemistry was performed on consecutive sections $(7 \mu \mathrm{m})$ of paraffin-embedded pancreatic tissue [38]. Insulin-stained sections were used for morphometric analysis. Quantitative evaluation was performed using the Histolab 6.0.5 software (Microvision Instruments). Beta cell mass was calculated by multiplying the relative beta cell area by pancreas weight. Slides were counterstained with haematoxylin.

\section{Statistical analysis}

Results are presented as means \pm SEM. $\mathrm{n}$ represents the number of mice. Differences between groups were compared with the two-tailed unpaired Student's $t$ test. A $p$ value of $<0.05$ was considered significant.

\section{Results}

Constitutive production of SOCS2 in beta cells

To study the role of SOCS2 in beta cells, we generated transgenic mice constitutively producing SOCS2 specifically in beta cells. Note that normally the SOCS2 protein is present at very low levels in the basal condition. Two separate transgenic sublines were analysed. Our transgenic mice had normal fertility and survival, and had a Mendelian transgene distribution. Since the same phenotype was obtained for males and females, we show only results observed with males. We verified the constitutive expression of Socs2 in pancreatic islets by r-t PCR (Fig. 1a) and
Fig. 1 Generation of transgenic mice constitutively producing SOCS2 in beta cells. a Constitutive Socs 2 transgene expression. Islets were isolated from transgenic ( $\beta$ SOCS2, black bar) and wild-type (WT, white bar) mice ( $n=10$ in each group). RNA was extracted and analysed by r-t PCR. b Total extracts from 200 isolated islets from $\beta$ SOCS2 and WT mice were prepared and analysed by western blot with antibody to SOCS2. Antibody to tubulin was used as a control. c, d Total pancreas was isolated from tg or WT mice $(n=3)$, fixed and embedded in paraffin. Immunohistochemistry was performed with antibodies to SOCS2 or to insulin. Representative images show the restrictive production of SOCS2 in BSOCS2 mice and in insulin-producing cells. Scale bar, $20.25 \mu \mathrm{m}$ $\mathbf{a}$

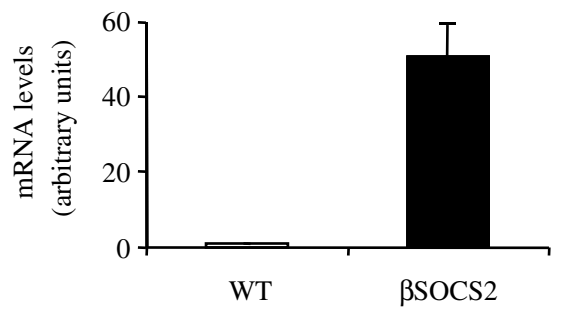

c

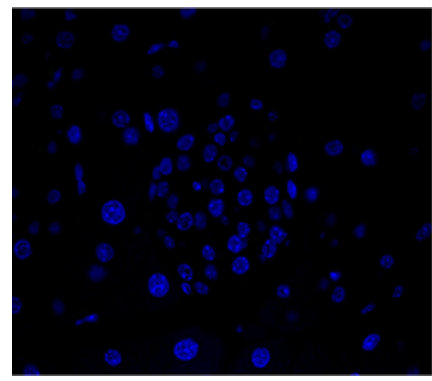

WT

d

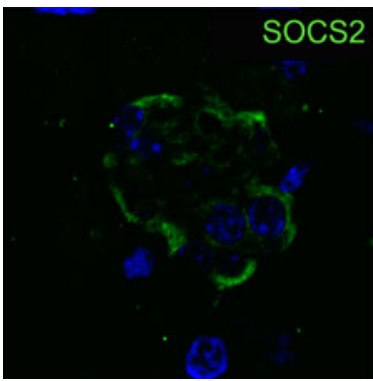

b
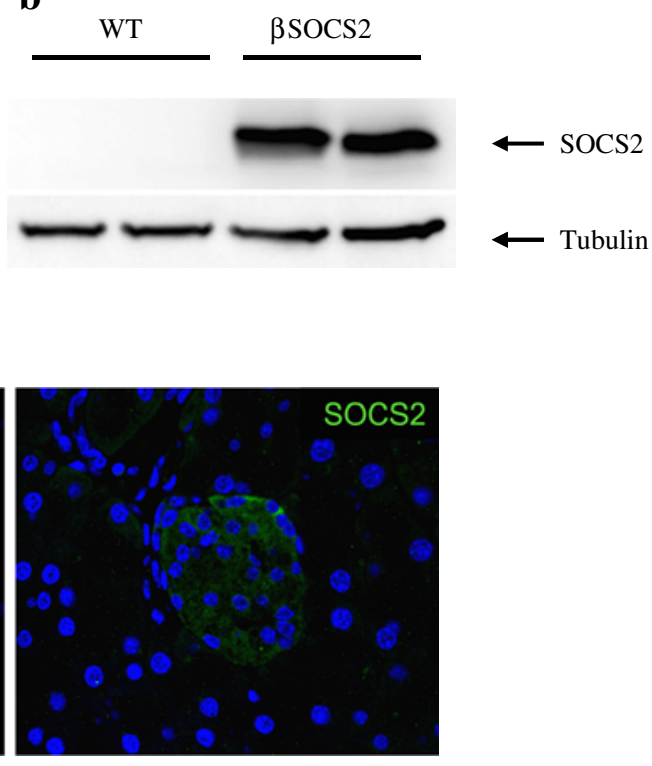

BSOCS2

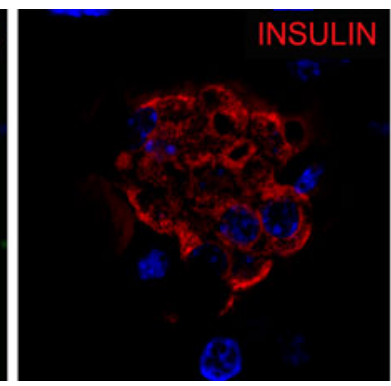

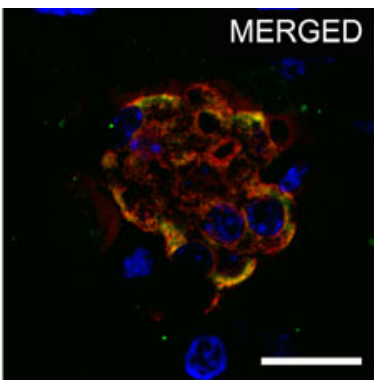


western blotting (Fig. 1b). Moreover, by immunohistochemistry we demonstrated that SOCS2 is detected exclusively in $\beta$ SOCS2 pancreatic islets (Fig. 1c), and that this signal corresponded exactly with insulin staining (Fig. 1d).

Phenotypic analysis of $\beta$ SOCS2 mice

Body weight Animals on chow or high-fat diet were weighed every week. As shown in Fig. 2a, no difference
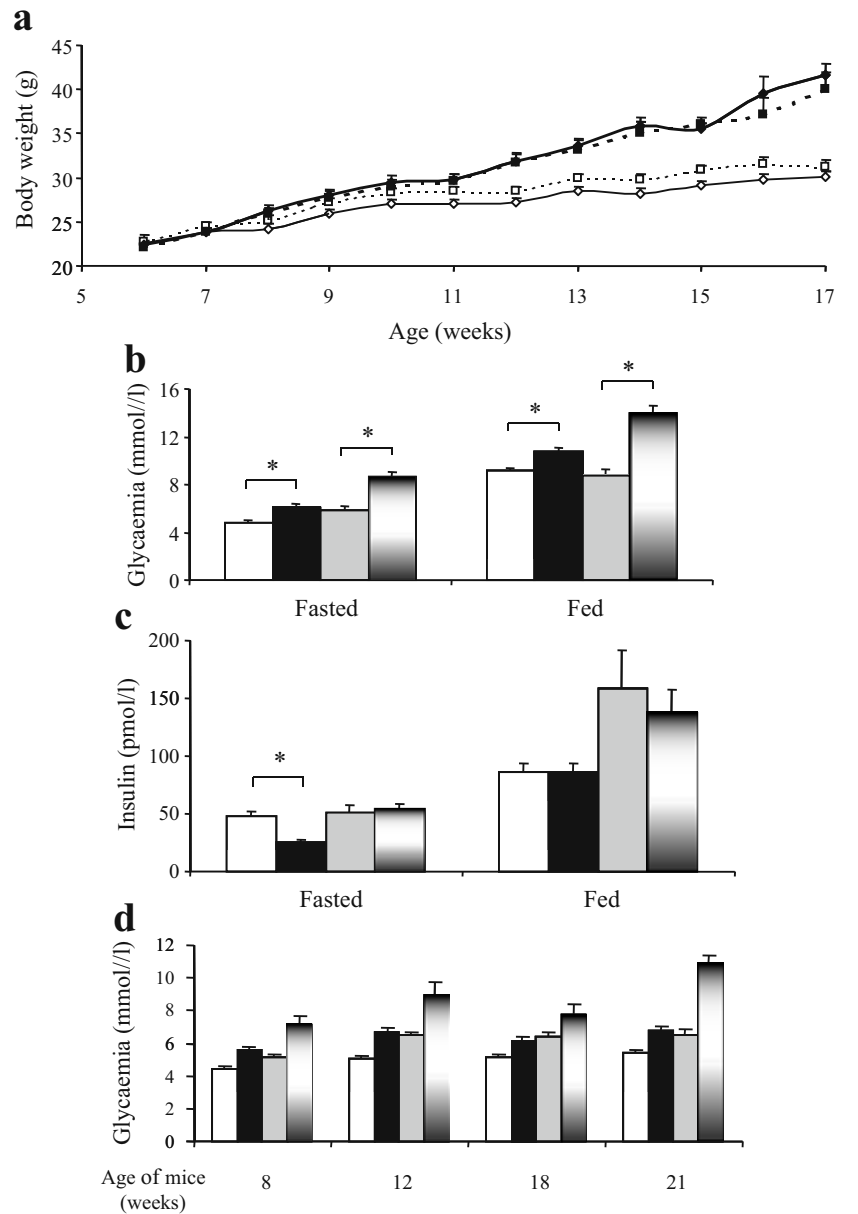

Fig. 2 Metabolic study of $\beta$ SOCS 2 transgenic mice. a $\beta$ SOCS 2 mice have a body weight similar to WT. Mice on chow diet (WT, $n=15$, regular discontinuous line; $\beta$ SOCS2, $n=15$, regular continuous line) or on HFD (WT, $n=15$, bold discontinuous line; $\beta$ SOCS $2, n=15$, bold continuous line) were weighed once a week starting at 6 weeks of age and for 11 weeks. b, c $\beta$ SOCS2 mice are hyperglycaemic but only slightly hypoinsulinaemic. Glycaemia (b) and insulinemia (c) were measured in the serum of 12-week-old mice under overnight fasted or fed conditions. Four groups were analysed: WT mice on chow diet ( $n=10$; white bars), $\beta$ SOCS2 mice on chow diet ( $n=8$; black bars), WT mice on HFD ( $n=5$; grey bars), and $\beta$ SOCS 2 mice on HFD ( $n=5$; black and white bars). ${ }^{*} p<0.05$. d Glycaemia was measured in the serum of 8-21-week-old mice in overnight fasted conditions. Same groups as described in $\mathbf{b}$, c. Hyperglycaemia of tg mice is significant in all conditions $(* p<0.05)$ in body weight was observed for transgenic (tg) compared with wild-type (WT) mice on the two diets.

Serum variables Glycaemia and insulinaemia were measured at different ages. Results obtained with 12-week-old mice are presented in Fig. 2b, c. Blood glucose levels in BSOCS2 mice were significantly higher than in WT mice, and this pattern is exacerbated on a high-fat diet (Fig. 2b). Concerning insulinaemia, $\beta$ SOCS2 mice on a chow diet are hypoinsulinaemic in fasted conditions compared with WT mice, in correlation with their slight hyperglycaemia (Fig. 2c). However, we did not observe such hypoinsulinaemia in fed conditions with chow or high-fat diet. Hyperglycaemia in $\beta$ SOCS2 mice only slightly increased with age (Fig. 2d).

Glucose tolerance As $\beta$ SOCS2 mice were hyperglycaemic compared with WT mice, we analysed their glucose tolerance (Fig. 3a, b). $\beta$ SOCS2 transgenic mice on chow and high-fat diet clearly suffered from glucose intolerance when exposed to a glucose challenge by either intraperitoneal (Fig. 3a) or oral (Fig. 3b) administration. The difference between tg and WT animals was significant at all time points studied. While the glucose intolerance of tg mice was already detectable on the chow diet, it was exacerbated on the high-fat diet. The glucose tolerance tests shown were performed on 12-week-old animals. To summarise, $\beta$ SOCS2 animals suffer from severe glucose intolerance, which is consistent with their hyperglycaemia. Our phenotypic analysis reveals that $\beta$ SOCS2 mice are severely glucose-intolerant. In addition, insulin tolerance tests did not reveal insulin resistance in $\beta$ SOCS2 mice (data not shown). Further, no pronounced worsening of the phenotype, i.e. development of overt diabetes, was observed on a high-fat diet. Considering the hallmarks of the phenotype of our mice, we favoured the idea that their hyperglycaemia was due to insufficient insulin secretion rather than to a dysfunction of peripheral tissues.

Insulin secretion To evaluate the insulin secretory response of $\beta$ SOCS2 mice compared with WT mice, we analysed insulin secretion induced by glucose and arginine in 15-week-old mice. Secretagogues were injected intraperitoneally and insulinaemia was measured from 2 to $30 \mathrm{~min}$ after injection. As previously described, glucose-stimulated insulin secretion is biphasic in WT animals (Fig. 3c), i.e. a rapid and transient spike at $2 \mathrm{~min}$, followed by a second phase from 10 to $30 \mathrm{~min}$. Remarkably, in tg mice the first secretion peak is completely abolished, while the second phase is severely dampened. This secretory defect was confirmed using arginine, which in the presence of low glucose induces a main secretion spike at 2 min (Fig. 3d). 


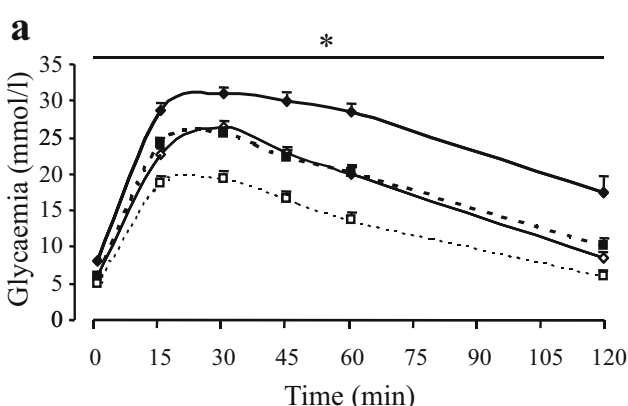

C

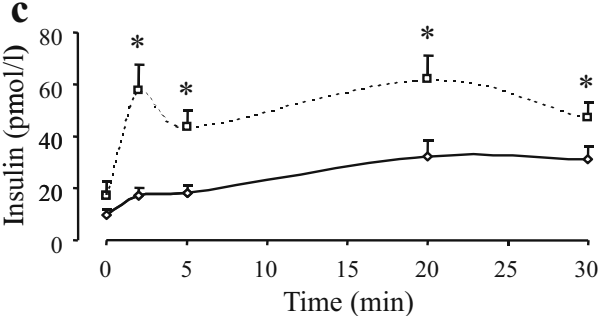

Fig. $3 \beta$ SOCS2 mice are glucose-intolerant. a, b GTTs in $\beta$ SOCS2 transgenic mice on chow (regular continuous line) and HFD (bold continuous line), and WT on chow (regular discontinuous line) and HFD (bold discontinuous line). Intraperitoneal IPGTTs (a) $(n=10$ in each group) and OGTTs (b) ( $n=5$ in each group) were performed on 15 -week-old mice after a $16 \mathrm{~h}$ fast (overnight), and glucose was given $(2 \mathrm{mg} / \mathrm{g})$ intraperitoneally and orally, respectively. c, d Insulin b

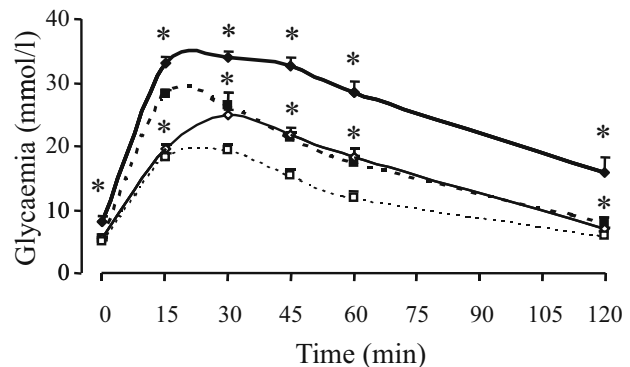

d

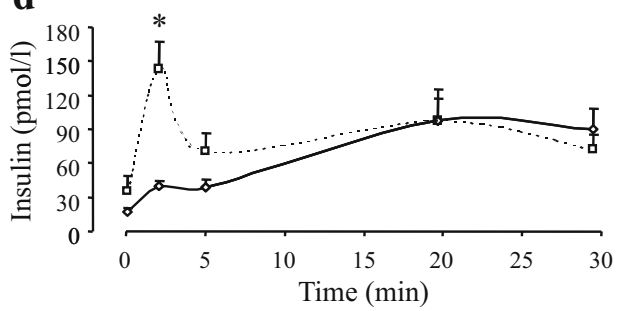

secretion in intact animals (15 weeks old). Overnight starved mice were challenged with glucose $(2 \mathrm{mg} / \mathrm{g})(\mathbf{c})$ or arginine $(3 \mathrm{mg} / \mathrm{g})(\mathbf{d})$, and serum was collected at different time points after intraperitoneal injection. Circulating insulin levels were quantified using an insulin ELISA kit (WT, discontinuous line, $n=15 ; \beta$ SOCS2, continuous line, $n=15) .{ }^{*} p<0.05$ $\mathbf{a}$
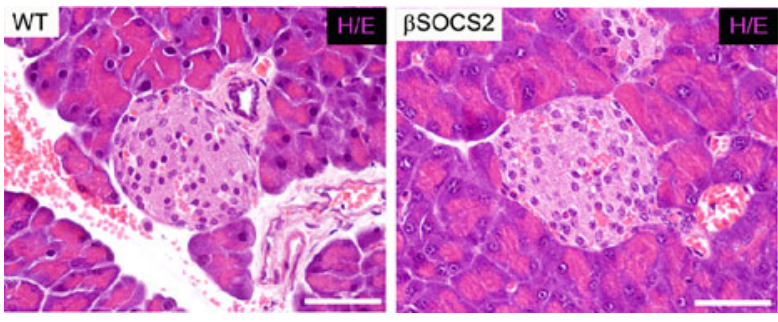

c

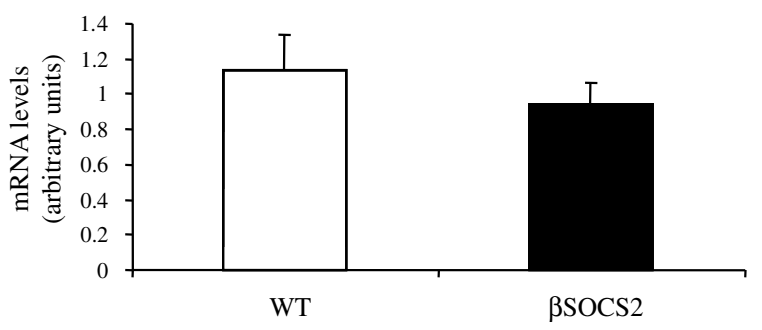

Fig. 4 a, b Morphometric analysis. Pancreases were extracted from WT and $\beta$ SOCS2 mice (15-20 weeks old), fixed in paraformaldehyde and embedded in paraffin. Pancreatic sections $7 \mu \mathrm{m}$ thick were stained with antibody to insulin and counterstained with haematoxylin/eosin $(\mathrm{H} / \mathrm{E})$. a A representative image of $\mathrm{H} / \mathrm{E}$ staining is shown; WT on the left and $\beta$ SOCS 2 on the right. $\mathbf{b}$ The beta cell mass was calculated by multiplying the percentage of insulin-positive area by the pancreas weight ( $n=4$ for each group). Quantitative evaluation was performed

\section{b}

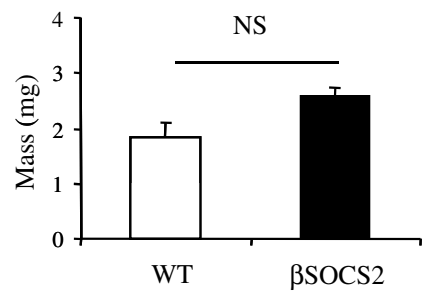

d

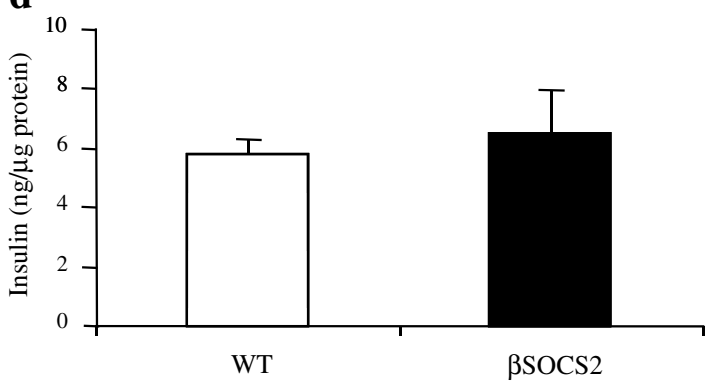

using Histolab 6.0.5 software (WT, white bar; $\beta$ SOCS2, black bar). c Insulin mRNA expression. Total RNA was extracted from isolated islets (WT, white bar, $n=10 ; \beta$ SOCS2, black bar, $n=10)$ mice $(10$ 15 weeks old), reverse transcribed and analysed by SYBR Green $r-t$ PCR using insulin-specific primers. d Insulin was extracted from whole pancreas with acid/alcohol solution and quantified by ELISA (WT, white bar, $n=3$; $\beta$ SOCS2, black bar, $n=3$ ). Scale bar, $40 \mu \mathrm{m}$ 
Islet biology of $\beta$ SOCS2 mice

Morphometry To search for defects in the pancreas of ßSOCS2 mice that could explain their insulin secretory defect, we performed islet morphometry. Results of a representative experiment are shown in Fig. $4 a$, b. No significant variation was found in $\beta$ SOCS 2 mice compared with WT mice. The beta cell mass of mice fed with a high-fat diet was, as expected, enlarged in WT mice, and this was found to a similar extent with tg mice (data not shown). To sum up, the altered insulin secretion in BSOCS2 mice is unlikely to be due to a reduction in beta cell mass.

Insulin mRNA expression and content Using r-t PCR, we found that the insulin mRNA levels were similar in tg and WT animals (Fig. 4c). A similar pattern was obtained for insulin content in whole pancreas (Fig. 4d). This suggests that the defect in $\beta$ SOCS2 mice may concern insulin maturation and/or secretion rather than its production.

Beta cell function in isolated islets

Insulin secretion To investigate whether the defective insulin secretion seen in $\beta$ SOCS2 mice was generated in vivo by noxious environmental conditions or was the consequence of an autonomous islet dysfunction, we looked at the secretory response of isolated islets induced by several secretagogues. We took advantage of stimuli such as glucose, $\mathrm{KCl}$, arginine and glibenclamide, which b

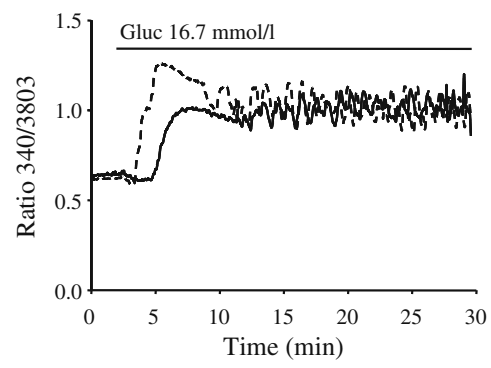

e

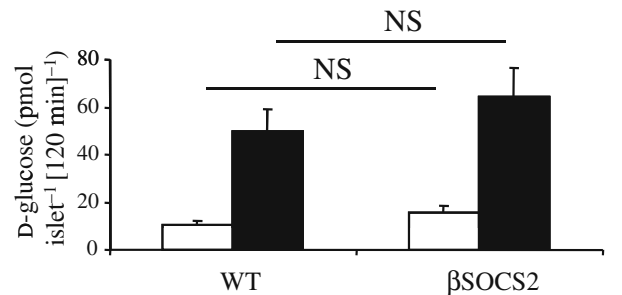

a

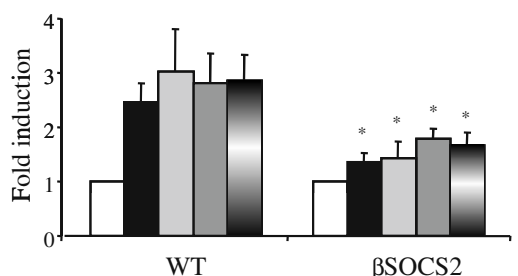

c

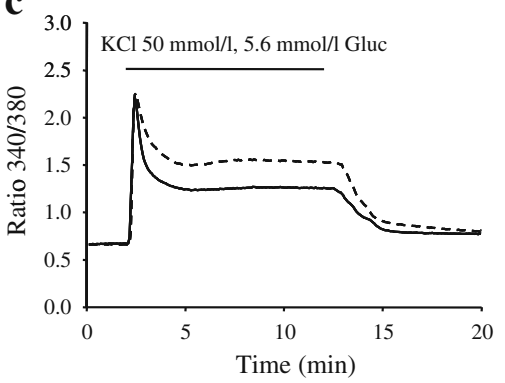

f d

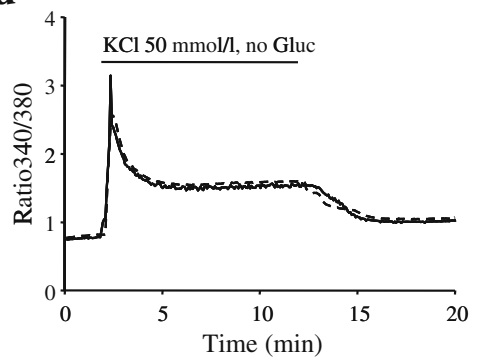

g
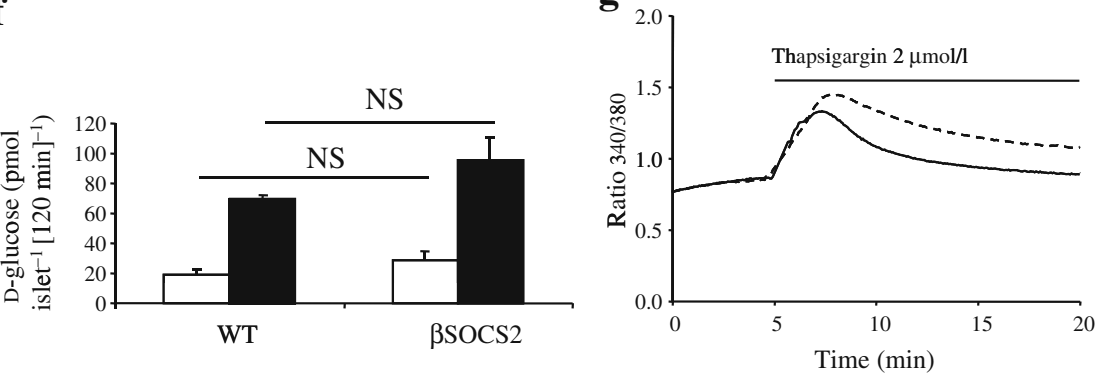

Fig. 5 a Insulin secretion in isolated islets. Isolated islets from WT $(n=5-9)$ and $\beta$ SOCS2 $(n=5-9)$ were exposed to $2.8 \mathrm{mmol} / 1$ glucose (white bars), $20 \mathrm{mmol} / 1$ glucose (black bars), arginine $20 \mathrm{mmol} / 1$ (light grey bars), $\mathrm{KCl} 30 \mathrm{mmol} / \mathrm{l}$ (dark grey bars) and glibenclamide $1 \mu \mathrm{mol} / \mathrm{l}$ (black and white bars). Non-glucose secretagogues were tested in the presence of $2.8 \mathrm{mmol} / \mathrm{l}$ glucose. Insulin levels were quantified in the supernatant fraction of isolated islets $1 \mathrm{~h}$ after stimulation and normalised to intra-islet insulin content. Results are expressed as a multiple of $2.8 \mathrm{mmol} / 1$ glucose condition. b-d Cytosolic free $\mathrm{Ca}^{2+}$ concentration in response to $16.7 \mathrm{mmol} / 1$ glucose $(\mathbf{b}), 50 \mathrm{mmol} / 1 \mathrm{KCl}$ in the presence of $5.6 \mathrm{mmol} / \mathrm{l}$ glucose (c) and $50 \mathrm{mmol} / \mathrm{l} \mathrm{KCl}$ without glucose (d). Experiments were performed on perfused islets from WT ( $n=4$, discontinuous line) and $\beta \operatorname{SOCS} 2(n=4$, continuous line). e,f Glucose oxidation and ${ }^{3} \mathrm{H}_{2} \mathrm{O}$ production were measured in isolated islets (WT, $n=3$; $\beta \mathrm{SOCS} 2, n=4$ ) in the presence of 2.8 (white bars) and $16.7 \mathrm{mmol} / \mathrm{l}$ glucose (black bars). $\mathrm{g}$ Estimation of the calcium content in the endoplasmic reticulum (ER). $\left[\mathrm{Ca}^{2+}\right]_{\mathrm{i}}$ was measured in the presence of $2 \mu \mathrm{mol} / 1$ thapsigargin. Increase in $\left[\mathrm{Ca}^{2+}\right]_{\mathrm{i}}$ corresponds to a calcium leakage from ER in WT ( $n=4$, discontinuous line) and $\beta \operatorname{SOCS} 2(n=4$, continuous line) isolated islets. Representative of four individual experiments in each case. ${ }^{*} p<0.05$. NS, not significant 
are known to activate the secretory machinery by different means. Interestingly, we found that insulin secretion in response to the tested secretagogues was significantly reduced in BSOCS2 islets compared with WT (Fig. 5a). These observations confirmed the results obtained in vivo, and suggest that the defect is likely to occur at some common distal step in the secretory machinery.

Cytosolic free calcium concentration $\left(\left[\mathrm{Ca}^{2+}\right]_{i}\right)$ Here we determined the $\left[\mathrm{Ca}^{2+}\right]_{\mathrm{i}}$ in $\beta$ SOCS2 and WT islets in response to glucose and $\mathrm{KCl}$. As shown in Fig. 5b, SOCS islets showed a delayed and reduced initial phase. Thus, the increase in $\left[\mathrm{Ca}^{2+}\right]_{\mathrm{i}}$ over the baseline value $(0-3 \mathrm{~min})$ recorded during the first phase $(3-10 \mathrm{~min})$ was reduced by $45 \%(p<0.05)$. In the presence of low glucose $(5.6 \mathrm{mmol} / \mathrm{l}), \mathrm{KCl}$-induced $\left[\mathrm{Ca}^{2+}\right]_{\mathrm{i}}$ increase over the baseline value $(0-2 \mathrm{~min})$ was reduced by $21 \%(p<0.05)$ in $\beta$ SOCS2 islets (Fig. 5c). However, in the absence of glucose, the increase in $\left[\mathrm{Ca}^{2+}\right]_{\mathrm{i}}$ in response to $\mathrm{KCl}$ is similar in WT and $\beta$ SOCS2 islets (Fig. 5d), suggesting that glucose metabolism may be altered in transgenic mice.

Glucose metabolism Next we measured glucose oxidation and ${ }^{3} \mathrm{H}_{2} \mathrm{O}$ production reflecting the complete process of glucose metabolism (Fig. 5e, f). Our analysis revealed unaltered glucose metabolism in islets from $\beta$ SOCS2 compared with tg mice, and this corresponds with the unchanged levels of insulin mRNA. Thus, the perturbation leading to the insulin secretion defect in $\beta$ SOCS2 mice concerns the regulation of $\left[\mathrm{Ca}^{2+}\right]_{\mathrm{i}}$, but is unlikely to be related to glucose metabolism and plasma membrane depolarisation.

Endoplasmic reticulum calcium $\left(\left[\mathrm{Ca}^{2+}\right]_{E R}\right)$ content It is well documented that calcium contained in the endoplasmic reticulum (ER) participates in the regulation of $\left[\mathrm{Ca}^{2+}\right]_{\mathrm{i}}$ in beta cells. In particular, $\mathrm{Ca}^{2+}$ release from ER in response to extracellular $\mathrm{Ca}^{2+}$ entrance (called CICR, for $\mathrm{Ca}^{2+}$-induced $\mathrm{Ca}^{2+}$ release) may be implicated in controlling insulin secretion. Therefore, we estimated $\left[\mathrm{Ca}^{2+}\right]_{\mathrm{ER}}$ by quantifying $\left[\mathrm{Ca}^{2+}\right]_{i}$ in the presence of thapsigargin, which blocks the capture of $\mathrm{Ca}^{2+}$ from cytosol to ER lumen by inhibiting the action of SERCAs. As expected, in WT islets, an increase in $\left[\mathrm{Ca}^{2+}\right]_{\mathrm{i}}$ resulting from the leak of $\mathrm{Ca}^{2+}$ from ER was observed. Interestingly, this effect $(5-20 \mathrm{~min})$ was reduced by $48 \%(p<0.01)$ in islets from tg mice (Fig. $5 \mathrm{~g})$. A similar result was observed in the presence of cyclopiazonic acid (data not shown).

In conclusion, the secretory defect due to constitutive production of SOCS2 in beta cells is probably operating independently of plasma membrane depolarisation, and is due, at least partially, to a decrease in intracellular $\mathrm{Ca}^{2+}$ stores.
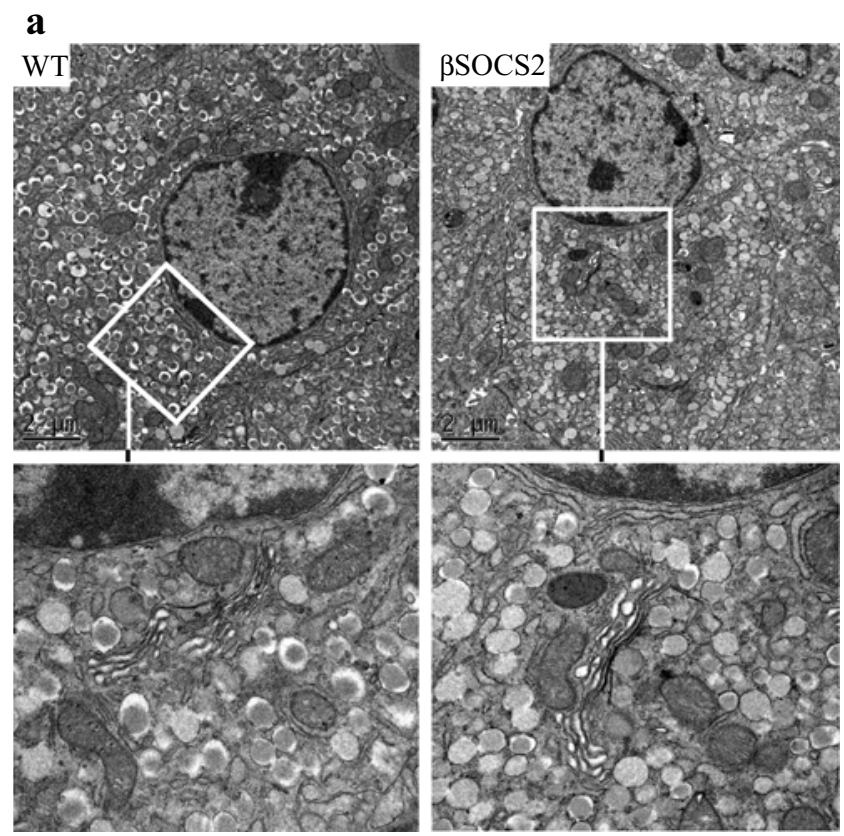

b
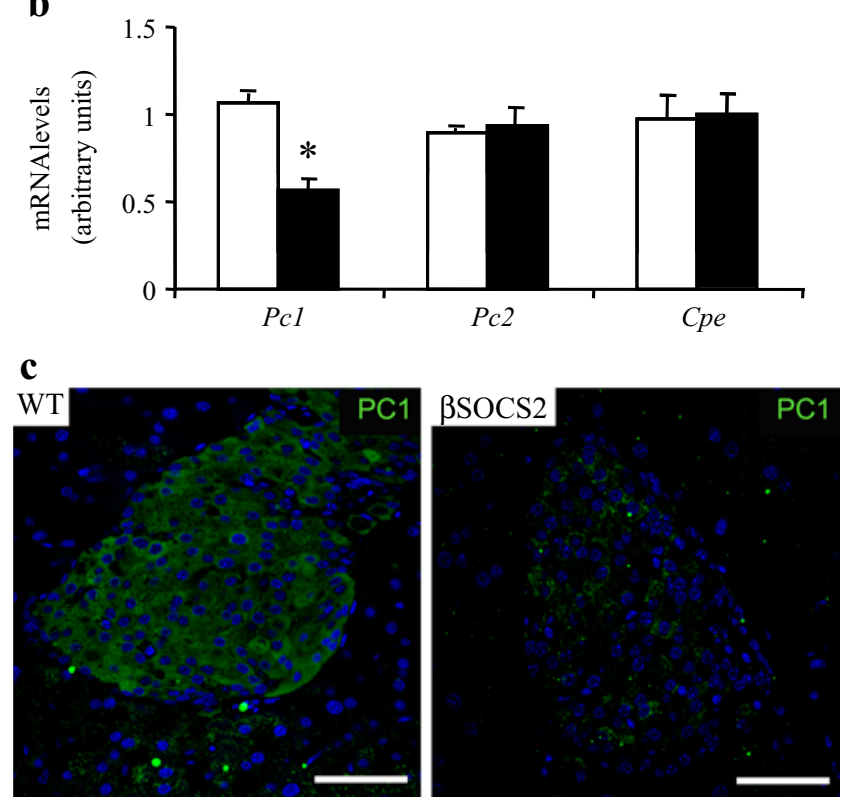

Fig. 6 a Ultrastructural analysis of islets. Pancreases from 15-weekold WT $(n=3)$ and $\beta$ SOCS2 $(n=3)$ mice were fixed in glutaraldehyde/ PFA and embedded in epoxy resin. Ultrathin sections stained with lead citrate were examined by transmission electronic microscopy. Representative pictures are shown. Black scale bar $=2 \mu \mathrm{m}$. b Expression of genes coding for enzymes involved in insulin maturation. Total RNA was extracted from isolated islets (WT, white bar, $n=6 ; \beta$ SOCS2, black bar, $n=5$ ), reverse transcribed and analysed by SYBR Green real-time PCR using primers specific to $P c-1, P c-2$ and $C p e$. c PC1 protein content in WT and $\beta$ SOCS 2 mice $(n=3$ for each group, 15 weeks old). Representative images of immunohistochemistry analysis using a specific PC1 antibody are shown. ${ }^{*} p<0.05$. Scale bar, $53.66 \mu \mathrm{m}$ 
Insulin maturation and exocytosis

Insulin granule appearance Electron microscopic analysis revealed in $\beta$ SOCS2 beta cells an altered structure of the insulin secretory granules (Fig. 6a). Whereas insulin granules are abundant in WT mice and contain a classical dense core, in tg mice they are smaller and do not appear as mature granules. This perturbed granule pattern in tg animals could reflect a defect in proinsulin maturation.

mRNA levels of enzymes implicated in proinsulin maturation The insulin packaged in mature granules derives from proinsulin, which is cleaved inside the secretory granules by several enzymes, including prohormone convertase 1/3 (PC1), pro-hormone convertase 2 (PC2) and carboxypeptidase $\mathrm{E} / \mathrm{H}$ (CPE). In trying to explain the altered structure of insulin granules in tg mice, we analysed by r-t PCR the mRNA levels of these key enzymes. In tg islets we found a $50 \%$ decrease in $P c 1$ mRNA levels (Fig. 6b), but unchanged $P c 2$ and $C p e$ mRNA levels.

PC1 protein levels in $\beta$ SOCS 2 mice Next, we investigated whether, in accordance with the r-t PCR results, the PC1 protein levels are decreased in tg mice. As shown in Fig. 6c, immunohistochemistry staining of PC1 is severely impaired in islets from $\beta$ SOCS 2 mice compared with WT.

To conclude, constitutive production of SOCS2 in beta cells could perturb the proinsulin maturation by affecting the appropriate levels of the key prohormone convertase PC1.

Circulating levels of proinsulin in $\beta$ SOCS2 mice compared with WT

To confirm the fact that $\beta$ SOCS2 mice have perturbed proinsulin maturation, we quantified by a specific ELISA test the levels of circulating proinsulin. Interestingly, the proinsulin content was increased in sera of tg animals compared with WT (Fig. 7a). This pattern was observed for all the conditions tested (fasted/fed; chow/HFD). In addition, by normalising the circulating proinsulin levels to those of insulin (shown in Fig. 2c), we showed that the ratio of proinsulin/total insulin is robustly increased in tg animals (Fig. 7b). Thus, in WT mice $18.3 \%$ proinsulin and $81.7 \%$ mature insulin were found, while in tg mice $58 \%$ proinsulin and $42 \%$ mature insulin were present. This shift in favour of proinsulin was observed on both chow and a high-fat diet.

\section{Discussion}

Here we approached the role of SOCS2 in pancreatic beta cell functioning. To this end, we generated $\beta$ SOCS2 transgenic mice constitutively producing SOCS2 protein specifically in beta cells. Remarkably, starting from 810 weeks the $\beta$ SOCS 2 mice were overtly hyperglycaemic and glucose-intolerant. This phenotype, observed in two separate tg sublines (ESM Fig. 1), was not profoundly worsened with age or with a high-fat diet, and the tg mice do not develop overt diabetes. A key feature of our mice is their altered insulin secretion in vivo. Counterintuitively, this was not due to a reduced beta cell mass, which was in fact even slightly augmented in $\beta$ SOCS 2 mice compared with WT mice. It is known that GH plays a key role in the regulation of beta cell mass [39] and that SOCS2 is a potent inhibitor of GH signalling. However, our data suggest that GH signalling was probably not affected by SOCS2, since no islet hypoplasia was detected. Our result correlates with observations made with genetically modified animals in which constitutive production of SOCS2 does not necessarily inhibit GH signalling [40, 41]. In addition, Billestrup et al. showed a reduced beta cell mass in mice constitu-

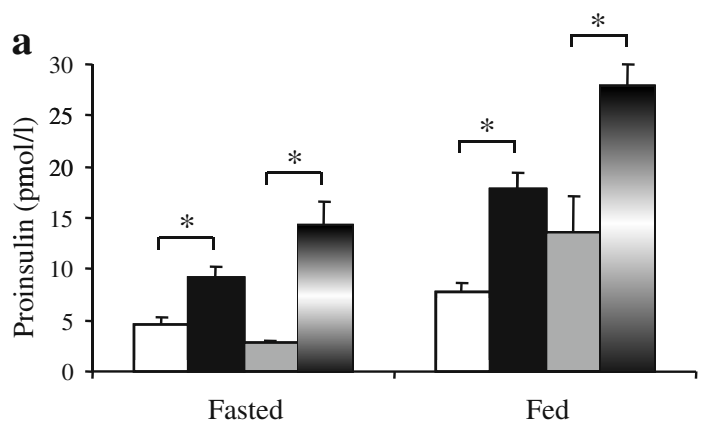

Fig. 7 a Circulating proinsulin levels. Using a specific ELISA kit, we measured proinsulin levels in the serum of 12-week-old WT and $\beta$ SOCS2 mice on chow or HFD and in fasted or fed conditions (WT chow diet, white bars, $n=10$; $\beta$ SOCS 2 chow diet, black bars, $n=8$; WT HFD, grey bars, $n=5$; $\beta$ SOCS2 HFD, black and white bars, $n=3$ ).

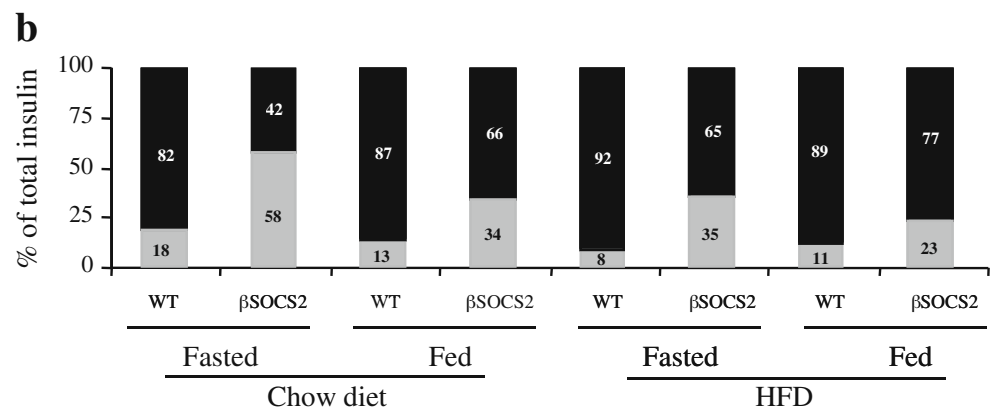

b Ratio of proinsulin to insulin in the serum of WT and $\beta$ SOCS2 mice. Proinsulin levels (grey) were expressed as a percentage of total insulin levels. Mature insulin levels (black) were estimated as $(100 \%-\%$ proinsulin). ${ }^{*} p<0.05$ 
tively producing SOCS3 in these cells. Together, these results suggest that in beta cells SOCS3 is more potent than SOCS2 to inhibit GH signalling. Using morphometric analysis, we found that high-fat diet-induced hyperplasia of beta cell mass occurs in tg as well as in WT mice. This suggests that the molecular events involved in compensatory islet hyperplasia, thought to be largely dependent on insulin action [42], were not perturbed by SOCS2 constitutive production. Taken together, our data would indicate that SOCS2 does not affect beta cell proliferation and/or replication, but, rather, beta cell functioning.

Indeed, it appears that constitutive SOCS2 production in beta cells leads to reduced insulin secretion in response to several secretagogues (glucose, $\mathrm{KCl}$, arginine and glibenclamide). This defect is likely to be intrinsic to beta cells, as it is also observed with isolated islets. The molecular mechanisms implicated in insulin secretion are well known [43]. In brief, after its uptake extracellular glucose is metabolised, generating ATP. The increased ATP/ADP ratio leads to potassium channel closure, plasma membrane depolarisation and opening of voltage-dependent $\mathrm{Ca}^{2+}$ channels. The rise in intracytoplasmic $\mathrm{Ca}^{2+}$ drives exocytosis of mature insulin contained in secretory granules. In our $\beta$ SOCS2 mice the insulin secretion defect appears to occur at a major insulin secretion-coupling step, since it is found with different types of secretagogues. Looking at distal molecular steps implicated in insulin secretion, we showed in islets from tg mice that the glucose-induced increase in $\left[\mathrm{Ca}^{2+}\right]_{\mathrm{i}}$ is delayed and reduced, and that the potassium-induced increase in the presence of low glucose has a perturbed profile. However, in the absence of glucose, $\mathrm{KCl}$, which increases $\left[\mathrm{Ca}^{2+}\right]_{\mathrm{i}}$ mainly by $\mathrm{Ca}^{2+}$ entry from the extracellular compartment, gave a similar $\left[\mathrm{Ca}^{2+}\right]_{\mathrm{i}}$ profile in tg and WT mice. While this could suggest that the defective insulin secretion in tg was linked to decreased glucose metabolism, we found this not to be the case. Thus, molecular events unrelated to glucose metabolism, but implicated in calcium fluxes, may be altered in tg islets, leading to impaired insulin secretion. Interestingly, we found that $\mathrm{ER} \mathrm{Ca}^{2+}$ stores are decreased in islets from tg mice. The ER serves multiple important functions, including post-translational protein modification and folding, assembly of secretory proteins and $\mathrm{Ca}^{2+}$ storage. In particular, the ER participates in the control of $\left[\mathrm{Ca}^{2+}\right]_{\mathrm{i}}$ by the release of calcium from its intrinsic store (CICR) and by recapturing $\mathrm{Ca}^{2+}$ from the cytosol into its lumen. Calcium depletion from the ER lumen perturbs ER function and eventually beta cell survival [44]. Thus, the decrease in calcium contents in both cytosol and ER in our tg model corresponds with its insulin secretion defect. However, how SOCS2 alters $\mathrm{Ca}^{2+}$ fluxes in beta cells remains to be defined. Due to the high sensitivity of beta cells to ER stress, we investigated whether constitutive SOCS2 production in islets would induce ER stress, shutting down beta cell function. As demonstrated in ESM Fig. 2, no increase in C/EBP homologous protein (CHOP) levels or inhibition of X-box binding protein-1 (XBP-1) splicing was detected in $\beta$ SOCS2 $\operatorname{tg}$ islets. Moreover, the levels of SERCA2 protein and mRNA are unaltered in SOCS2-overproducing islets (ESM Figs 2 and 3). Thus, the ability of SOCS2 to deplete ER of calcium is independent of SERCA2 downregulation and does not lead to detectable ER stress.

In addition to its crucial role in insulin exocytosis [45], $\left[\mathrm{Ca}^{2+}\right]_{\mathrm{i}}$ favours the maturation of proinsulin to insulin inside the granules extruded from the distal endoplasmic reticulum $[46,47] .\left[\mathrm{Ca}^{2+}\right]_{\mathrm{ER}}$ is also fundamental for processing enzymes implicated in the conversion of proinsulin to insulin (such as $\mathrm{PC} 1 / 3$ and $\mathrm{PC} 2$ ) and their inclusion inside the secretory granules. In accordance with these data, insulin granules in BSOCS2 islets appear as immature granules with reduced 'condensed' material. The secretory granules contain the enzymes necessary for cleavage of proinsulin to insulin plus C-peptide, i.e. PC-1/ 3, PC2 and CPE [48]. Remarkably, we found that PC-1/3 production was reduced at the mRNA and protein level in islets constitutively producing SOCS2. Importantly, PC- $1 / 3$ is the main enzyme implicated in proinsulin cleavage. Steiner et al. showed that the defect of proinsulin processing is more pronounced in PC- $1 / 3$ null mice than in PC-2 null mice $[49,50]$. Indeed, in PC-1/3 null mice proinsulin and intermediate molecules represent $85 \%$ of total immunoreactive insulin, whereas they represent only $5.3 \%$ in WT mice. Interestingly, the heterozygous $\mathrm{PC}-1 / 3$ null mice also exhibit altered proinsulin/insulin ratio and suffer from glucose intolerance. This correlates with our results demonstrating that a reduction by approximately half of $P c 1 / 3$ mRNA expression, with unchanged $P c-2$ and $C p e$ levels, is sufficient to alter proinsulin maturation and glucose tolerance. Finally, we found that in our tg mice the level of circulating proinsulin is robustly increased. In correlation with this fact, the proinsulin contained in whole pancreas is significantly increased in $\beta$ SOCS 2 mice (ESM Fig. 4). Thus, as shown for the PC-1/3 null mice, the ratio of proinsulin/mature insulin is strongly augmented. However, how constitutive SOCS2 production leads to PC-1/3 downregulation represents a provocative question. It is interesting to remember that inflammatory stimuli can lead to activation of PC-1 production [51]. Indeed, in neuronal cells leukaemia inhibitory factor (LIF), IL6 or lipopolysaccharide (LPS) treatment is associated with increased $P c 1$ mRNA level. It is well established that these stimuli are able to induce SOCS protein production, and that SOCS inhibit the signal that has led to their production. Moreover, LIF, LPS and IL6 mediate their intracellular actions through the gp130 receptor and the Jak/STAT pathway. As previously mentioned, SOCS proteins are potent negative 
modulators of Jak/STAT signalling. While our most urgent challenge is to understand how SOCS proteins can affect expression of genes involved in proinsulin processing, our observations are particularly intriguing in light of recent reports showing that the confirmed type 2 diabetes-related genetic loci, TCF7L2, CDKAL1 and SLC30A8, are associated with impaired proinsulin conversion $[52,53]$.

To summarise, we report that constitutive production of SOCS2 in beta cells alters intracellular $\mathrm{Ca}^{2+}$ stores and is associated with decreased proinsulin maturation and impaired hormone secretion. This leads to pronounced glucose intolerance, but is insufficient to induce per se the development of overt diabetes. Our data reveal that a major actor in regulation of signalling by cytokines and hormones in beta cells, such as SOCS2, can impact on proinsulin processing and insulin secretion, and hence participate in beta cell failure, predisposing to diabetes.

Acknowledgements We are grateful to C. Hinault for expertise with islet isolation. We thank V. Melgarejo and L. Moya for technical assistance in transmission electron microscopy and immunohistochemical analysis. E. Cognard was supported by a grant from FRM (Fondation pour la Recherche Médicale, Paris, France) and P. Lebrun was supported by a grant from the EFSD/MSD programme (20052008). Our research in Nice was supported by INSERM, Université de Nice-Sophia Antipolis, le Conseil Général des Alpes-Maritimes, le Conseil Régional PACA and the European Community (Grant FP6 Eugene2 (LSHM-CT-2004-512013)). Research performed in F. Bosch laboratory was supported by a grant from 'Plan Nacional $\mathrm{I}+\mathrm{D}+\mathrm{I}$ (SAF2005-01262), Spain' and by Grant FP6 Eugene2 (LSHM-CT2004-512013). The work performed in A. Herchuelz laboratory was supported by grants from the Belgian Fund for Scientific Research (FRSM 3.4593.04, 3.4527.08).

Duality of interest The authors declare that there is no duality of interest associated with this manuscript.

\section{References}

1. Feng DD, Zhao YF, Luo ZQ, Keating DJ, Chen C (2008) Linoleic acid induces $\mathrm{Ca}^{2+}$-induced inactivation of voltage-dependent $\mathrm{Ca}^{2+}$ currents in rat pancreatic beta-cells. J Endocrinol 196:377-384

2. Ling Z, Kiekens R, Mahler T et al (1996) Effects of chronically elevated glucose levels on the functional properties of rat pancreatic beta-cells. Diabetes 45:1774-1782

3. Maedler K, Sergeev P, Ris F et al (2002) Glucose-induced beta cell production of IL-1beta contributes to glucotoxicity in human pancreatic islets. J Clin Invest 110:851-860

4. Zhao YF, Feng DD, Hernandez M, Chen C (2007) 3T3-L1 adipocytes induce dysfunction of MIN6 insulin-secreting cells via multiple pathways mediated by secretory factors in a co-culture system. Endocrine 31:52-60

5. Yoshimura A, Naka T, Kubo M (2007) SOCS proteins, cytokine signalling and immune regulation. Nat Rev Immunol 7:454-465

6. Emanuelli B, Peraldi P, Filloux C et al (2001) SOCS-3 inhibits insulin signaling and is up-regulated in response to tumor necrosis factor-alpha in the adipose tissue of obese mice. J Biol Chem 276:47944-47949
7. Emanuelli B, Peraldi P, Filloux C, Sawka-Verhelle D, Hilton D, van Obberghen E (2000) SOCS-3 is an insulin-induced negative regulator of insulin signaling. J Biol Chem 275:15985-15991

8. Greenhalgh CJ, Rico-Bautista E, Lorentzon M et al (2005) SOCS2 negatively regulates growth hormone action in vitro and in vivo. J Clin Invest 115:397-406

9. Lindberg K, Ronn SG, Tornehave D et al (2005) Regulation of pancreatic beta-cell mass and proliferation by SOCS-3. J Mol Endocrinol 35:231-243

10. Ueki K, Kondo T, Kahn CR (2004) Suppressor of cytokine signaling 1 (SOCS-1) and SOCS-3 cause insulin resistance through inhibition of tyrosine phosphorylation of insulin receptor substrate proteins by discrete mechanisms. Mol Cell Biol 24:5434-5446

11. Chong MM, Thomas HE, Kay TW (2001) gamma-Interferon signaling in pancreatic beta-cells is persistent but can be terminated by overexpression of suppressor of cytokine signaling-1. Diabetes 50:2744-2751

12. Chong MM, Thomas HE, Kay TW (2002) Suppressor of cytokine signaling-1 regulates the sensitivity of pancreatic beta cells to tumor necrosis factor. J Biol Chem 277:27945-27952

13. Karlsen AE, Ronn SG, Lindberg K et al (2001) Suppressor of cytokine signaling 3 (SOCS-3) protects beta-cells against interleukin-1beta- and interferon-gamma-mediated toxicity. Proc Natl Acad Sci USA 98:12191-12196

14. Emanuelli B, Glondu M, Filloux C, Peraldi P, van Obberghen E (2004) The potential role of SOCS-3 in the interleukin-1betainduced desensitization of insulin signaling in pancreatic betacells. Diabetes 53(Suppl 3):S97-S103

15. Bruun C, Heding PE, Ronn SG et al (2009) Suppressor of cytokine signalling-3 inhibits tumor necrosis factor-alpha induced apoptosis and signalling in beta cells. Mol Cell Endocrinol 311:32-38

16. Jacobsen ML, Ronn SG, Bruun C et al (2009) IL-1beta-induced chemokine and Fas expression are inhibited by suppressor of cytokine signalling-3 in insulin-producing cells. Diabetologia 52:281-288

17. Ronn SG, Hansen JA, Lindberg K, Karlsen AE, Billestrup N (2002) The effect of suppressor of cytokine signaling 3 on GH signaling in beta-cells. Mol Endocrinol 16:2124-2134

18. Lorentzon M, Greenhalgh CJ, Mohan S, Alexander WS, Ohlsson C (2005) Reduced bone mineral density in SOCS-2-deficient mice. Pediatr Res 57:223-226

19. Michaylira CZ, Simmons JG, Ramocki NM et al (2006) Suppressor of cytokine signaling-2 limits intestinal growth and enterotrophic actions of IGF-I in vivo. Am J Physiol Gastrointest Liver Physiol 291:G472-G481

20. Goldshmit Y, Greenhalgh CJ, Turnley AM (2004) Suppressor of cytokine signalling-2 and epidermal growth factor regulate neurite outgrowth of cortical neurons. Eur J Neurosci 20:2260-2266

21. Ransome MI, Goldshmit Y, Bartlett PF, Waters MJ, Turnley AM (2004) Comparative analysis of CNS populations in knockout mice with altered growth hormone responsiveness. Eur J Neurosci 19:2069-2079

22. Turnley AM, Faux CH, Rietze RL, Coonan JR, Bartlett PF (2002) Suppressor of cytokine signaling 2 regulates neuronal differentiation by inhibiting growth hormone signaling. Nat Neurosci 5:1155-1162

23. Machado FS, Johndrow JE, Esper L et al (2006) Antiinflammatory actions of lipoxin A4 and aspirin-triggered lipoxin are SOCS-2 dependent. Nat Med 12:330-334

24. Schultheis B, Carapeti-Marootian M, Hochhaus A, Weisser A, Goldman JM, Melo JV (2002) Overexpression of SOCS-2 in advanced stages of chronic myeloid leukemia: possible inadequacy of a negative feedback mechanism. Blood 99:1766-1775

25. Sutherland KD, Lindeman GJ, Choong DY et al (2004) Differential hypermethylation of SOCS genes in ovarian and breast carcinomas. Oncogene 23:7726-7733 
26. Wikman H, Kettunen E, Seppanen JK et al (2002) Identification of differentially expressed genes in pulmonary adenocarcinoma by using cDNA array. Oncogene 21:5804-5813

27. Kato H, Nomura K, Osabe D et al (2006) Association of singlenucleotide polymorphisms in the suppressor of cytokine signaling 2 (SOCS2) gene with type 2 diabetes in the Japanese. Genomics 87:446-458

28. Sladek R, Rocheleau G, Rung J et al (2007) A genome-wide association study identifies novel risk loci for type 2 diabetes. Nature 445:881-885

29. Zeggini E, Weedon MN, Lindgren CM et al (2007) Replication of genome-wide association signals in UK samples reveals risk loci for type 2 diabetes. Science 316:1336-1341

30. Thorens B, Guillam MT, Beermann F, Burcelin R, Jaquet M (2000) Transgenic reexpression of GLUT1 or GLUT2 in pancreatic beta cells rescues GLUT2-null mice from early death and restores normal glucose-stimulated insulin secretion. J Biol Chem 275:23751-23758

31. Nicholson SE, Willson TA, Farley A et al (1999) Mutational analyses of the SOCS proteins suggest a dual domain requirement but distinct mechanisms for inhibition of LIF and IL-6 signal transduction. Embo J 18:375-385

32. Brissova M, Shiota M, Nicholson WE et al (2002) Reduction in pancreatic transcription factor PDX-1 impairs glucose-stimulated insulin secretion. J Biol Chem 277:11225-11232

33. Kulkarni RN, Wang ZL, Wang RM et al (1997) Leptin rapidly suppresses insulin release from insulinoma cells, rat and human islets and, in vivo, in mice. J Clin Invest 100:2729-2736

34. Van Eylen F, Lebeau C, Albuquerque-Silva J, Herchuelz A (1998) Contribution of $\mathrm{Na} / \mathrm{Ca}$ exchange to $\mathrm{Ca}^{2+}$ outflow and entry in the rat pancreatic beta-cell: studies with antisense oligonucleotides. Diabetes 47:1873-1880

35. Hutton JC, Sener A, Malaisse WJ (1979) The stimulus-secretion coupling 4-methyl-2-oxopentanoate-induced insulin release. Biochem J 184:303-311

36. Malaisse WJ, Garcia-Morales P, Gomis R et al (1986) The coupling of metabolic to secretory events in pancreatic islets: inhibition by 2-cyclohexene-1-one of the secretory response to cyclic AMP and cytochalasin B. Biochem Pharmacol 35:37093717

37. Malaisse WJ, Rasschaert J, Zahner D, Sener A (1988) Hexose metabolism in pancreatic islets: the Pasteur effect. Diabetes Res 7:53-58

38. Paris M, Bernard-Kargar C, Berthault MF, Bouwens L, Ktorza A (2003) Specific and combined effects of insulin and glucose on functional pancreatic beta-cell mass in vivo in adult rats. Endocrinology 144:2717-2727
39. Nielsen JH, Galsgaard ED, Moldrup A et al (2001) Regulation of beta-cell mass by hormones and growth factors. Diabetes 50 (Suppl 1):S25-S29

40. Metcalf D, Greenhalgh CJ, Viney E et al (2000) Gigantism in mice lacking suppressor of cytokine signalling-2. Nature 405:1069-1073

41. Greenhalgh CJ, Metcalf D, Thaus AL et al (2002) Biological evidence that SOCS-2 can act either as an enhancer or suppressor of growth hormone signaling. J Biol Chem 277:40181-40184

42. Okada T, Liew CW, Hu J et al (2007) Insulin receptors in betacells are critical for islet compensatory growth response to insulin resistance. Proc Natl Acad Sci USA 104:8977-8982

43. Henquin JC (2009) Regulation of insulin secretion: a matter of phase control and amplitude modulation. Diabetologia 52:739-751

44. Eizirik DL, Cardozo AK, Cnop M (2008) The role for endoplasmic reticulum stress in diabetes mellitus. Endocr Rev 29:42-61

45. Rutter GA, Tsuboi T, Ravier MA (2006) $\mathrm{Ca}^{2+}$ microdomains and the control of insulin secretion. Cell Calcium 40:539-551

46. Guest PC, Bailyes EM, Hutton JC (1997) Endoplasmic reticulum $\mathrm{Ca}^{2+}$ is important for the proteolytic processing and intracellular transport of proinsulin in the pancreatic beta-cell. Biochem J 323 (Pt 2):445-450

47. Hoppa MB, Collins S, Ramracheya R et al (2009) Chronic palmitate exposure inhibits insulin secretion by dissociation of $\mathrm{Ca}$ (2+) channels from secretory granules. Cell Metab 10:455-465

48. Assmann A, Hinault C, Kulkarni RN (2009) Growth factor control of pancreatic islet regeneration and function. Pediatr Diabetes 10:14-32

49. Zhu X, Orci L, Carroll R, Norrbom C, Ravazzola M, Steiner DF (2002) Severe block in processing of proinsulin to insulin accompanied by elevation of des-64, 65 proinsulin intermediates in islets of mice lacking prohormone convertase 1/3. Proc Natl Acad Sci USA 99:10299-10304

50. Zhu X, Zhou A, Dey A et al (2002) Disruption of $\mathrm{PC} 1 / 3$ expression in mice causes dwarfism and multiple neuroendocrine peptide processing defects. Proc Natl Acad Sci USA 99:1029310298

51. Li QL, Jansen E, Friedman TC (1999) Regulation of prohormone convertase 1 (PC1) by gp130-related cytokines. Mol Cell Endocrinol 158:143-152

52. Kirchhoff K, Machicao F, Haupt A et al (2008) Polymorphisms in the TCF7L2, CDKAL1 and SLC30A8 genes are associated with impaired proinsulin conversion. Diabetologia 51:597-601

53. Stancakova A, Kuulasmaa T, Paananen J et al (2009) Association of 18 confirmed susceptibility loci for type 2 diabetes with indices of insulin release, proinsulin conversion, and insulin sensitivity in 5,327 nondiabetic Finnish men. Diabetes 58:2129-2136 